\title{
HEAVY METALS IN STREAM SEDIMENTS AFFECTED BY A LANDFILL AND ASSOCIATED IMPACT ON GROUNDWATER QUALITY
}

\author{
Koutsopoulou, E., Tsolis-Katagas, P. and Papoulis, D. \\ University of Patras, Department of Geology, Section of Earth Materials, 26500 Patras, Greece, ekout- \\ sop@upatras.gr
}

\begin{abstract}
Sanitary landfill facilities are essential to modern societies as repositories for municipal solid wastes. However, they always entrain a certain risk of environmental impact. For this reason monitoring is essential to their operation. In the present work, the environmental impact of such a landfill is studied. Soil samples were collected in and around the landfill and their mineralogy was studied. Top layers of stream sediments were collected to examine possible dispersion of pollutants in the environment. Chemical analyses showed enrichment in $\mathrm{As}, \mathrm{Cu}, \mathrm{Zn}$, and $\mathrm{Pb}$ in the stream sediments compared to uncontaminated samples. The presence of anions such as chloride, sulphate and phosphate adsorbed on clay minerals suggest the interaction of stream sediments with run-off water from the landfill.

The groundwater near the landfill site was characterised as not potable and not suitable for irrigation purposes, because some parameters such as $\mathrm{NO}_{3}^{-}$and $\mathrm{Cl}^{-}$were close or exceeded the permissible limits given by EE, EPA and WHO.
\end{abstract}

Key words: sanitary landfill, clay minerals, groundwater, heavy metals, stream sediments.

\section{Introduction}

Waste management policies concerning municipal landfills play an important role on preventing the emissions of contaminants, eliminating potential health hazards and preserving the environment. Landfills should hold no risks for the environment and that means that the transport of contaminants should be confined and restricted from reaching the natural environment. As stated by the Swiss Waste Management Standards of 1986 and the legislation in most European countries (Council Directive 99/31/EC), municipal waste deposits have to be compatible with the environment. Sanitary landfills require that a composite liner comprising a geomembrane and a clay mineral liner according to the multi-barrier system should be used at the bottom of the waste disposal site (Stief, 1986; Technical Instructions Hazardous Wastes, 1991; Hermanns Stengele and Plötze, 2000; Kalbe et al., 2002). This concept is essential for the avoidance of leachate migration from the landfill boundaries and its release into the surrounding environment, which may cause ground water pollution and other environmental impacts. Compacted clayey soils are widely used as landfill liners in order to isolate waste materials from surrounding environments, and to prevent the heavy metals commonly found in landfill leachate from migrating into groundwater (Chalermyanont et al., 2009). However, various studies have reported elevated concentrations of metals in stream sediments originating from landfill contamination sources. Studies of increased $\mathrm{Cu}, \mathrm{Pb}, \mathrm{Zn}, \mathrm{Cd}, \mathrm{Ag}$, and $\mathrm{Ba}$ concentrations in stream sediments from landfills and water treatment facilities have been reported (Mantei and Coon- 


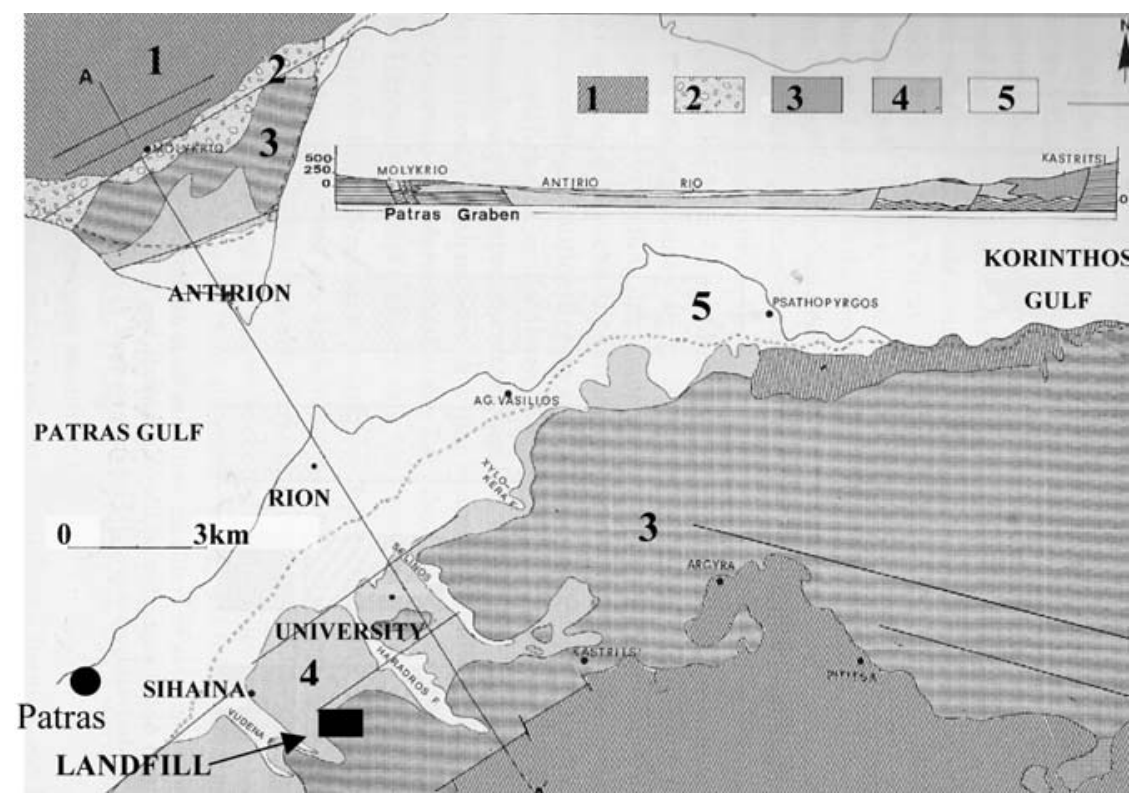

Fig. 1: The location of the sanitary landfill of the Municipality of Patras: 1. limestone, flysch, chert, 2. alluvial deposits, 3. fluvial deposits, 4. undivided Plio-Pleistocene 5. recent deposits (Doutsos et al., 1985).

rod, 1989; Mantei and Foster, 1991; Gonçalves et al., 2004). In the latter study the contamination of the stream sediments was a result of run-off waters from the landfill. Infiltration of water through the top cover of the landfill can also lead to surface and groundwater contamination (Kjeldsen et al., 1993; Fatta et al., 1999).

In the present work, clay materials from an operating waste disposal facility in Patras, NW Peloponnese, Greece, were collected in order to determine the different clay minerals present and to evaluate the consequences of solid waste disposal in the landfill. Stream sediments were examined for the presence of contaminants to examine possible dispersion of pollutants in the environment. Moreover, the extent of the leachate adverse impacts on the groundwater of the area, and the pollution level of groundwater were investigated.

\section{The sanitary landfill of Patras}

The sanitary landfill of Patras is located near Ano Sihaina village, approximately $10 \mathrm{~km}$ southeast of the city of Patras (Fig. 1). The total available area of the plant is $400,000 \mathrm{~m}^{2}$, of which $70,000 \mathrm{~m}^{2}$ are developed as landfill area.

The geological and hydrogeological conditions of the landfill area are characterized by the presence of thick sequences of Plio-Pleistocene fine sediments (clayey marls, marls and siltstones) with lensoidal intercalation of sandstones and conglomerates, which do not sustain a considerable groundwater table (Zelilidis et al., 1998; Doutsos et al., 1988).

The studied area is located in the southern flanks of the Rio Graben (Fig. 1), which is an extensional structure controlled by ENE-WSW trending normal faults and the main direction of the extension is almost N-S (Doutsos et al., 1985). The landfill has been developed in a natural depression with 


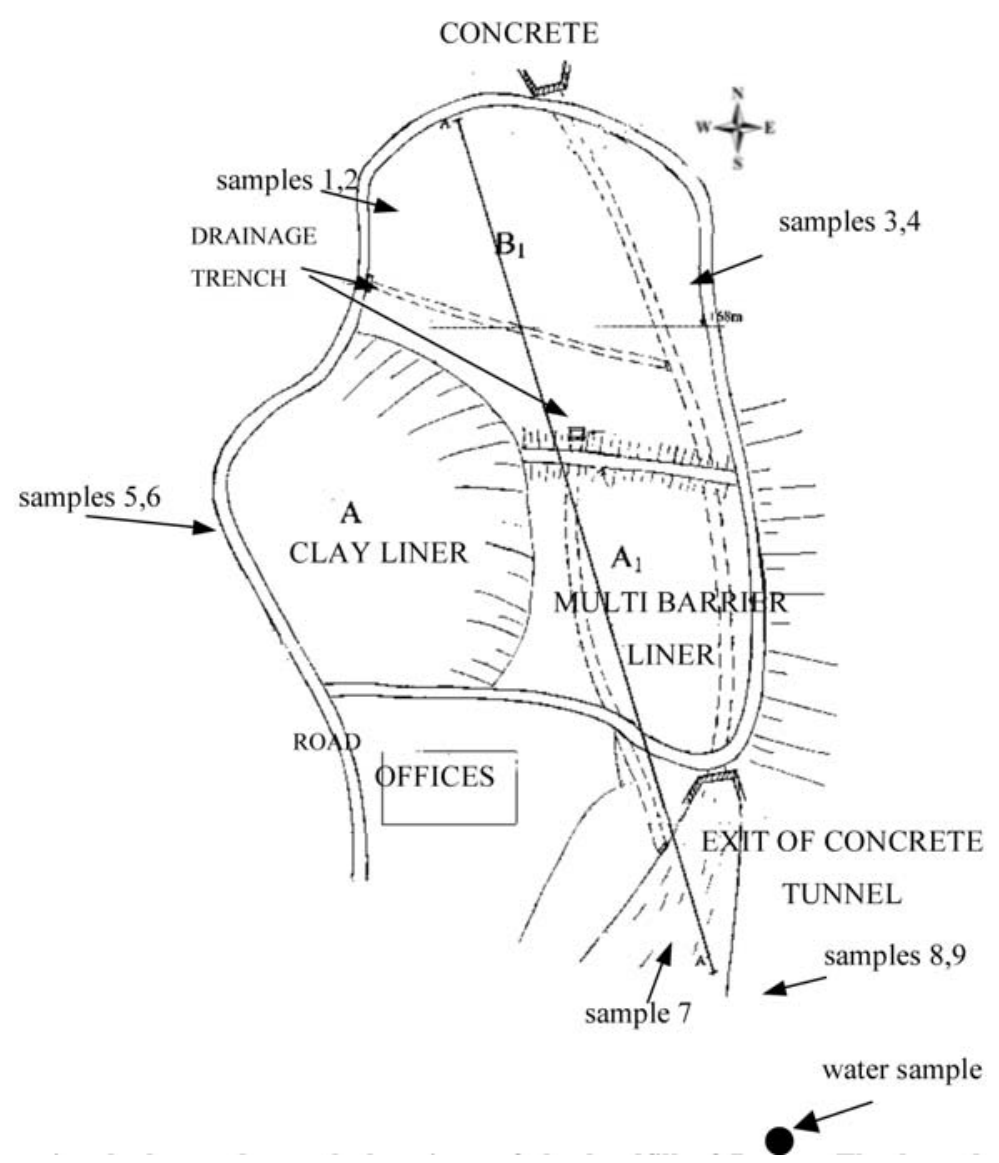

Fig. 2: Sectional plan and sample locations of the landfill of Patras. The boundary of the waste disposal site is outlined by the indication of the perimetrical road.

general axial direction $\mathrm{N}-\mathrm{S}$ and slope of $10^{\circ}$ to the $\mathrm{N}$, bounded to the west by a steep hillslope and to the east by a seasonal stream (Fig. 2).

The filling of the landfill is phased, divided in the areas $\mathrm{A}_{1}, \mathrm{~B}_{1}, \mathrm{~A}_{2}$ and $\mathrm{B}_{2}$. Prior to the construction of the new sanitary landfill, the Municipality of Patras preceded to the preparation of a part of the available area covering $15,000 \mathrm{~m}^{2}$ (phase A, Fig. 2). The filling of this phase, which is lined only with compacted clay for the protection of ground and groundwater, was completed in September 1995, when the operation of the new landfill commenced. Phase A is now restored and the landfill gas from the existing waste is extracted and flared.

The new landfill is sealed with a composite lining system that consists of a bottom clay lining layer of compacted clay, and an overlying geomembrane (HDPE) protected by geotextile. The protection of the landfill from surface water run-off and the subsequent decrease in leachate volume was accomplished by the construction of a reinforced concrete tunnel along the riverbed of the stream entering the site from the west in order to collect the streamwater off the site, the diversion of the stream bordering the site from the east and the construction of a drainage trench upgradient (south) and perimetrically of the whole area (KORONIS S.A, 1996). 


\section{Materials and methods}

\subsection{Sampling}

The landfill is located in clay-rich Pliocene-Pleistocene sediments (Fig. 2). Samples were collected from the material used as capping (samples 1,2,3,4), liner (samples 5,6) and from the downstream area of the landfill in order to determine the mineralogy and examine possible dispersion of pollutants in the surrounding area (samples $7,8,9$ ). One sample was collected from the top layers of a run-off water path since these layers correspond to the volume of sediment which is kept in direct contact with contaminated water for longer time periods (stream sediment - sample 7) (Fig. 2). Finally, a groundwater sample was collected from a downgradient-monitoring borehole in order to detect changes in water quality that may be caused by infiltration of run-off waters or the escape of leachate from the landfill.

\subsection{Methods}

The mineralogical composition of the clay material was determined by X-Ray Diffraction (XRD), using a Philips diffractometer PW1050/25, with Ni-filtered CuK $\alpha$ radiation. Briefly, oriented powder mounts of bulk samples were prepared by gently pressing the powder into the cavity holder and were scanned at $1^{\circ} 2 \theta / \mathrm{min}$ from 3 to $60^{\circ} 2 \theta$. The clay minerals were identified from three XRD patterns (i.e., after air-drying at $25^{\circ} \mathrm{C}$, with ethylene glycol treatment, and after heating at $490^{\circ} \mathrm{C}$ for 2 hours).

Clay minerals morphology and chemical composition of coexisting minerals were examined with Scanning Electron Microscopy (SEM), using a JEOL 6300 SEM equipped with an Energy Dispersive Spectrometer (EDS). The chemical composition of the minerals was determined using natural and synthetic standards and $20 \mathrm{kV}$ accelerating voltage with $10 \mathrm{nA}$ beam current. Microanalyses were performed on epoxy resin-impregnated polished and gold or carbon coated thin sections, and sample powders mounted directly on the sample holder.

Chemical analyses for major and trace elements were carried out in all samples by Instrumental Neutron Activation Analysis (INAA) and by Inductively Coupled Plasma (ICP-MS), using a Thermo Jarrell-Ash ENVIRO II ICP, and a Perkin Elmer Optima 3000 ICP, with the 4-acid (HF, $\mathrm{HClO}_{4}$, $\mathrm{HNO}_{3}$ and $\mathrm{HCl}$ ) digestion technique (Activation Laboratories, Canada).

Finally, chemical analysis of major and trace elements of the groundwater sample were carried out by Flame Atomic Absorption Spectrometry (FAAS) GBC AVANTA ${ }^{\circledR}$ using a HACH DR 4000 Spectrophotometer, and by ICP/MS using an ELAN 6100 Perkin Elmer ${ }^{\circledR}$ ICP.

\section{Results}

\subsection{Mineralogy}

X-ray diffraction patterns of oriented powder mounts revealed the presence of quartz, calcite, albite and clay minerals in all samples. The clay minerals are chlorite, smectite, illite, kaolinite and mixedlayer chlorite-smectite. Mixed-layer chlorite-smectite is identified by a peak at $14 \AA$ in the air-dried sample, which shifts to $15.5 \AA$ after treatment with ethylene glycol and at about $12 \AA$ after heating at $490^{\circ} \mathrm{C}$ for two hours. Chlorite is characterised by the presence of peaks at $14.2 \AA, 7.1 \AA, 4.74 \AA$ and $3.55 \AA$ which are not affected after ethylene glycol treatment and remain essentially unchanged after heating. Smectite is identified by a reflection at about $16.6 \AA$ after ethylene glycol solvation that collapses to $10 \AA$ after heating. Illite is identified by the presence of peaks at $10 \AA, 5 \AA$ and 3.3 $\AA ̊$ which remain unaffected by ethylene glycol solvation and heating (Moore and Reynolds, 1989). 

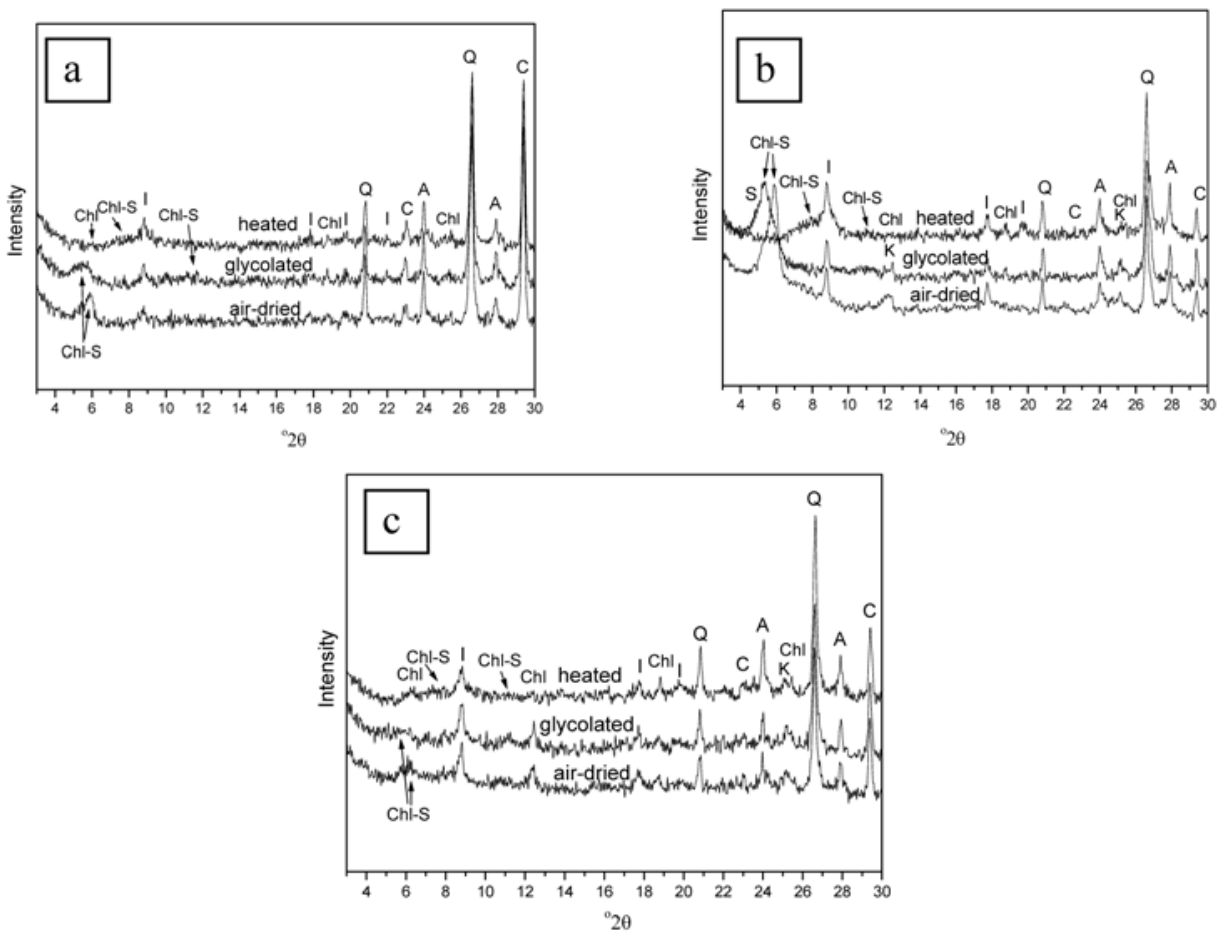

Fig. 3: X-ray diffraction patterns of representative bulk samples: a) material used as capping in the landfill, b) material used as lining in the landfill, c) stream sediment. Chl-S: chlorite-smectite, I: illite, Chl: chlorite, K: kaolinite, Q: quartz, C: calcite, A: albite, S: smectite.

Kaolinite is present in the material used as lining in the landfill and is identified by the (001) and (002) reflections at $7.15 \AA$ and $3.58 \AA$ respectively. The XRD patterns of representative bulk samples collected from the capping material, the lining and the stream sediment are presented in Fig. 3 .

Clay minerals and especially smectite and mixed layer chlorite-smectite are more abundant in the material used as a liner in the landfill compared to the samples collected from the capping material and the stream sediment.

\subsection{Geochemistry}

Bulk sample chemical analyses for major elements were performed in all samples and are listed in Table 1. Samples 5, and 6 used in the liner have the highest $\mathrm{K}_{2} \mathrm{O}, \mathrm{Na}_{2} \mathrm{O}, \mathrm{Al}_{2} \mathrm{O}_{3}, \mathrm{Fe}_{2} \mathrm{O}_{3}$ and $\mathrm{SiO}_{2}$ content and the lowest $\mathrm{CaO}$ and Loss on Ignition (LOI) content, reflecting the abundance in clay minerals and calcite respectively. Trace elements analyses (Table 2) showed that the $\mathrm{As}, \mathrm{Cu}, \mathrm{Zn}, \mathrm{Pb}$ and $\mathrm{Ni}$ content is higher in the stream sediment (sample 7) compared to the uncontaminated samples. Since stream sediments are in contact with run-off waters from the landfill this could be an indication of contamination from the landfill. Trace elements $\mathrm{Ba}$ and $\mathrm{Sr}$ are mainly correlated with the presence of calcite and their relatively high content is attributed to the increased calcite content.

The minerals present in the stream sediment were also examined by SEM-EDS. Traces of $\mathrm{Cl}^{-}, \mathrm{SO}_{4}{ }^{2-}$ and $\mathrm{PO}_{4}{ }^{3-}$ were detected in many ED spectra of clay minerals. SEM-EDS analyses also revealed traces of $\mathrm{Cu}$ in clay minerals, associated with $\mathrm{Cl}^{-}$. 
Table 1. Bulk sample chemical analyses for major elements (wt\%).

\begin{tabular}{|c|c|c|c|c|c|c|c|c|c|c|c|c|}
\hline sample & $\mathrm{SiO}_{2}$ & $\mathrm{TiO}_{2}$ & $\mathrm{Al}_{2} \mathrm{O}_{3}$ & $\mathrm{Fe}_{2} \mathrm{O}_{3}$ & $\mathrm{MnO}$ & $\mathrm{MgO}$ & $\mathrm{CaO}$ & $\mathrm{Na}_{2} \mathrm{O}$ & $\mathrm{K}_{2} \mathrm{O}$ & $\mathrm{P}_{2} \mathrm{O}_{5}$ & $\mathrm{LOI}$ & Total \\
\hline 1 & 46.82 & 0.24 & 4.44 & 1.92 & 0.08 & 0.80 & 23.07 & 0.75 & 0.69 & 0.06 & 20.14 & 99.00 \\
\hline 2 & 38.94 & 0.29 & 5.11 & 2.14 & 0.08 & 0.99 & 26.47 & 0.77 & 0.78 & 0.08 & 24.52 & 100.18 \\
\hline 3 & 54.05 & 0.35 & 6.42 & 2.35 & 0.09 & 1.09 & 16.95 & 1.12 & 0.99 & 0.07 & 16.69 & 100.18 \\
\hline 4 & 62.41 & 0.47 & 8.30 & 3.55 & 0.07 & 1.37 & 9.29 & 1.39 & 1.26 & 0.07 & 11.57 & 99.75 \\
\hline 5 & 59.20 & 0.59 & 9.79 & 4.27 & 0.08 & 1.77 & 9.68 & 1.40 & 1.46 & 0.13 & 11.74 & 100.11 \\
\hline 6 & 59.97 & 0.56 & 9.56 & 4.20 & 0.10 & 1.75 & 8.88 & 1.46 & 1.43 & 0.11 & 10.76 & 98.79 \\
\hline 7 & 49.89 & 0.54 & 9.33 & 4.14 & 0.09 & 1.98 & 14.28 & 1.20 & 1.63 & 0.11 & 16.44 & 99.63 \\
\hline 8 & 64.34 & 0.45 & 7.32 & 2.77 & 0.09 & 1.17 & 9.72 & 1.32 & 1.18 & 0.08 & 10.35 & 98.79 \\
\hline 9 & 46.79 & 0.25 & 4.22 & 1.89 & 0.07 & 0.79 & 23.73 & 0.83 & 0.62 & 0.06 & 20.38 & 99.63 \\
\hline
\end{tabular}

Table 2. Bulk sample chemical analyses for trace elements (ppm).

\begin{tabular}{|c|c|c|c|c|c|c|c|c|}
\hline sample & $\boldsymbol{A s}$ & $\boldsymbol{C u}$ & $\mathbf{Z n}$ & $\boldsymbol{P b}$ & $\boldsymbol{N i}$ & $\boldsymbol{C r}$ & $\boldsymbol{B a}$ & $\boldsymbol{S} \boldsymbol{r}$ \\
\hline 2 & $<0.5$ & 20 & 30 & 11 & 57 & 150 & 135 & 318 \\
\hline 4 & 3.5 & 23 & 47 & 20 & 90 & 260 & 187 & 154 \\
\hline 5 & 4 & 32 & 61 & 24 & 106 & 292 & 196 & 136 \\
\hline 6 & 4.6 & 34 & 50 & 24 & 96 & 299 & 196 & 163 \\
\hline 7 & 6.5 & 39 & 82 & 18 & 117 & 252 & 420 & 151 \\
\hline
\end{tabular}

\subsection{Groundwater Chemistry}

Chemical analyses of major and trace elements of the groundwater sample from the downgradientmonitoring borehole are presented in Tables 3 and 4 . The water sample is characterized by a significant enrichment of $\mathrm{Ca}^{2+}$, alkalis, $\mathrm{HCO}_{3}^{-}, \mathrm{NO}_{3}{ }^{-}$and $\mathrm{Cl}^{-}$. As a result, the groundwater has the characteristics of $\left(\mathrm{Ca}^{2+}+\mathrm{Na}^{+}\right)-\mathrm{HCO}_{3}^{-}$- type water. This type of water is renewed due to continuous dilution by the addition of sporadic precipitation waters (Gibbs, 1970).

The concentrations of potential contaminants such as $\mathrm{SO}_{4}{ }^{2-}, \mathrm{NO}_{3}{ }^{-}$and $\mathrm{Cl}^{-}$were analyzed in order to identify possible human induced contamination. The concentration of $\mathrm{SO}_{4}{ }^{2-}$ is quite high for groundwater that is not related to mining operations but is still below drinkable limits. The $\mathrm{NO}_{3}{ }^{-}$concentration of the water sample is slightly below the drinking water standard $(10 \mathrm{mg} / \mathrm{L})$ and $\mathrm{Cl}^{-}$ concentration is quite high for water that is not characterized by seawater intrusion. The concentrations of most toxic elements such as $\mathrm{As}, \mathrm{Cd}, \mathrm{Co}, \mathrm{Cr}, \mathrm{Cu}, \mathrm{Fe}, \mathrm{Mn}, \mathrm{Ni}, \mathrm{Pb}, \mathrm{Se}$ and $\mathrm{U}$ were in very low values except for $\mathrm{Zn}$ which is slightly below drinking limits $(95 \mathrm{ppb})$ and could be attributed to human activities (Table 4). Ba and $\mathrm{Sr}$ concentrations are also relatively high but this is probably due to the mineralogy of the host rock.

\section{Discussion}

Fine-grained top layers of stream sediments have been used to study metal contamination in the 
Table 3. Selected cation and anion constituents ( $\mathrm{mg} / \mathrm{l})$ of groundwater).

\begin{tabular}{|c|c|c|c|c|c|}
\hline cation $(\boldsymbol{m g} / \boldsymbol{l})$ & $\begin{array}{c}\text { groundwater } \\
(\boldsymbol{m g} / \boldsymbol{l})\end{array}$ & $\begin{array}{c}\text { drinkable limits } \\
(\boldsymbol{m g} / \boldsymbol{l})\end{array}$ & $\begin{array}{c}\text { anion } \\
(\boldsymbol{m g} / \boldsymbol{l})\end{array}$ & $\begin{array}{c}\text { groundwater } \\
(\boldsymbol{m} \boldsymbol{g} / \boldsymbol{l})\end{array}$ & $\begin{array}{c}\text { drinkable limits } \\
(\boldsymbol{m g} / \boldsymbol{l})\end{array}$ \\
\hline$\left(\mathrm{Na}^{+}\right)$ & 47.5 & 150 & $\left(\mathrm{HCO}_{3}^{-}\right)$ & 377 & - \\
\hline$\left(\mathrm{K}^{+}\right)$ & 1.7 & 12 & $\left(\mathrm{SO}_{4}^{2-}\right)$ & 44 & 250 \\
\hline$\left(\mathrm{Mg}^{2+}\right)$ & 15.9 & 50 & $\left(\mathrm{NO}_{3}^{-}\right)$ & 9.68 & 10 \\
\hline$\left(\mathrm{Ca}^{2+}\right)$ & 192 & - & $\left(\mathrm{NO}_{2}^{-}\right)$ & 0 & 0.1 \\
\hline$\left(\mathrm{NH}_{4}^{+}\right)$ & 0 & 0.5 & $\left(\mathrm{PO}_{4}^{3-}\right)$ & 0.08 & - \\
\hline & & & $\left(\mathrm{Cl}^{-}\right)$ & 100.4 & 10 \\
\hline
\end{tabular}

Table 4. Trace elements $(\mu \mathrm{g} / \mathrm{l})$ in groundwater

\begin{tabular}{|c|c|c|c|c|c|}
\hline element & $\begin{array}{c}\text { concentration } \\
(\boldsymbol{\mu} / \boldsymbol{l})\end{array}$ & $\begin{array}{c}\text { drinkable limits } \\
(\boldsymbol{\mu} \boldsymbol{g} / \boldsymbol{l})\end{array}$ & element & $\begin{array}{c}\text { concentration } \\
(\boldsymbol{\mu} \boldsymbol{g} / \boldsymbol{l})\end{array}$ & $\begin{array}{c}\text { drinkable limits } \\
(\boldsymbol{\mu} \boldsymbol{g} / \boldsymbol{l})\end{array}$ \\
\hline$(\mathrm{As})$ & 0 & 6 & $(\mathrm{~Pb})$ & 0.088 & $15 / 0$ \\
\hline$(\mathrm{Ba})$ & 147.313 & - & $(\mathrm{Rb})$ & 0.404 & - \\
\hline$(\mathrm{Be})$ & 0 & 4 & $(\mathrm{Se})$ & 0.772 & 50 \\
\hline$(\mathrm{Cd})$ & 0.044 & 5 & $(\mathrm{Sr})$ & 565.13 & - \\
\hline$(\mathrm{Cr})$ & 1.113 & 50 & $(\mathrm{U})$ & 0.715 & 30 \\
\hline$(\mathrm{Cu})$ & 2.338 & - & $(\mathrm{V})$ & 0.691 & - \\
\hline$(\mathrm{Fe})$ & 0 & 200 & $(\mathrm{Zn})$ & 95.965 & 100 \\
\hline$(\mathrm{Ga})$ & 5.936 & - & $(\mathrm{B})$ & 35.632 & 1000 \\
\hline$(\mathrm{Li})$ & 7.882 & - & $(\mathrm{Co})$ & 0.57 & - \\
\hline$(\mathrm{Mn})$ & 4.625 & 50 & $(\mathrm{Mo})$ & 0 & - \\
\hline$(\mathrm{Ni})$ & 5.638 & 50 & & & \\
\hline
\end{tabular}

vicinity of landfills, since metals generally accumulate on smaller grain fractions of sediment because of the higher surface area-to-grain size ratio (Gibbs, 1973; Harding and Brown, 1978; Ramamoorthy and Rust, 1978; Sinex and Helz, 1981; Rule, 1986; Yanful et al., 1988; Mantei and Coonrod 1989). Therefore, the mineralogy of the material used in the landfill controls the possibility of pollutant escape in the environment (Hermanns Stengele and Plötze, 2000). The material used in the landfill is characterized by the presence of quartz, calcite and clay minerals: chlorite, smectite, illite and the mixed-layer chlorite-smectite. Kaolinite is also present, especially in the samples collected from the liner in the landfill, and in the stream sediment.

The results of the geochemical analyses show the abundance of $\mathrm{SiO}_{2}$ and $\mathrm{A}_{2} \mathrm{O}_{3}$ especially in the samples used as a clay liner and the stream sediment. Samples 5 and 6 (clay liner) are slightly richer in $\mathrm{SiO}_{2}$ than the stream sediment (sample 7) with $\mathrm{SiO}_{2}$ ranging to about $60 \%$ due to the presence of quartz. The higher percentage of total iron and $\mathrm{MgO}$ in the same samples could be ascribed to the presence of chlorite and the mixed layer chlorite-smectite. This was supported by SEM-EDS analyses of chlorite and chlorite-smectite, which showed $\mathrm{Mg}^{2+}$ and $\mathrm{Fe}^{2+}$ as the commonest divalent cations. 
The stream sediment is abundant in most trace elements (As, $\mathrm{Cu}, \mathrm{Zn}, \mathrm{Pb}, \mathrm{Ni}, \mathrm{Ba}$ ) (Table 2). To our knowledge no leakage from the clay barrier has occurred since the operations of the landfill commenced. However, during rainy periods, run-off waters that interact with waste being prepared for storage may flow out downstream. Stream sediments are in direct contact with contaminated water, especially when the flux is low enough (as in the present case), and could show some degree of contamination.

The different clay minerals present, determine the preferential adsorption for cationic heavy metal ions (Churchman et al., 2006) and this adsorption is strongly affected by the $\mathrm{pH}$ and the presence of anions in the solution (Cavallaro, 1982; McBride, 1985; Undabeytia et al., 2002). The presence of inorganic ligands such as $\mathrm{Cl}^{-}, \mathrm{SO}_{4}{ }^{2-}$ and $\mathrm{PO}_{4}{ }^{3-}$ may increase metal retention or strongly increase metal mobility depending on the type and amount of metal and ligands present, soil surface properties, soil solution composition, $\mathrm{pH}$ and redox conditions (McLean and Bledsoe, 1992). Specific adsorption of ions, such as $\mathrm{Cl}^{-}$, on the surface with variable charge, could increase the negative charge of the surface, thus enhancing $\mathrm{Cu}$ adsorption (Wang et al., 1987; Doula and Ioannou, 2003). In our case, SEM-EDS analyses revealed the presence of $\mathrm{Cl}^{-}, \mathrm{SO}_{4}{ }^{2-}$ and $\mathrm{PO}_{4}{ }^{3-}$ adsorbed on clay minerals in the stream sediment. The presence of $\mathrm{Cl}^{-}$and other anions seem to have enhanced the adsorption of $\mathrm{Cu}$ deriving from run-off waters from the landfill.

Groundwater is enriched in $\mathrm{Ca}^{2+}$ and $\mathrm{HCO}_{3}{ }^{-}$and can be characterized as fresh water since it is renewed from precipitation waters causing dissolution of salts. The decreasing order of the abundance of major cations in the water is $\mathrm{Ca}^{2+}>\mathrm{Na}^{+}>\mathrm{Mg}^{2+}>\mathrm{K}^{+}$. A comparison between the chemical composition of the groundwater and the catchment rocks indicates that the bedrock types may affect the water chemistry. The high concentration of $\mathrm{Ca}^{2+}$ may result from dissolution of calcite, which is one of the main components of the bedrock. Moreover, albite could be a source of $\mathrm{Na}^{+}$, and the mixed layer chlorite-smectite for $\mathrm{Mg}^{2+}$ and $\mathrm{Na}^{+}$. An additional source of $\mathrm{Na}^{+}$may also be the landfill. Illite may also be a source of $\mathrm{K}^{+}$.

The groundwater is not a source of domestic or drinking water in the area. However, it is used for agricultural irrigation in one case that we are aware of. The high concentrations in $\mathrm{NO}_{3}{ }^{-}$in the groundwater sample imply that nitrates could derive from agricultural chemicals or fertilizers in the soil. Nitrate is a naturally occurring chemical that is an important plant nutrient often used in fertilizers. Most human exposure arises from food, and drinking water. Nitrate ends up in drinking water due to agricultural run-off from fertilizer use, erosion of natural deposits, or from animal and human waste via septic tanks and sewage systems. Bacteria in the gut convert nitrate to nitrite, which is mostly responsible for any toxic effects observed (California Environmental Protection Agency, 1997; National Toxicology Program (NTP), 2002).

Chloride is relatively abundant in the water sample and suggests contamination through human activities. Chloride concentration in unpolluted waters is often below $10 \mathrm{mg} /$ litre and sometimes below $1 \mathrm{mg} /$ litre (Department of National Health and Welfare Canada, 1978). In groundwater $\mathrm{Cl}^{-}$could originate from anthropogenic sources, such as landfill leachate and the use of inorganic fertilizers, since potassium chloride is used in the production of fertilizers (Department of National Health and Welfare Canada, 1978). The mean $\mathrm{Cl}^{-}$concentration in several rivers in the UK was $11-42 \mathrm{mg} / \mathrm{litre}$ during 1974-81 (Brooker and Johnson, 1984). Evidence for a general increase in chloride concentrations in groundwater and drinking-water has been found (WHO, 1978). In the USA, aquifers prone to seawater intrusion have been found to contain chloride at concentrations ranging from 5 to $460 \mathrm{mg} /$ litre (Phelan, 1987), whereas contaminated wells in the Philippines have been reported to have an average chloride concentration of $141 \mathrm{mg} /$ litre (Morales, 1987). 
According to drinking water standards, the concentrations of all trace elements in the studied waters were below the maximum contaminant level (MCL) values given by European Council Directive (1980), U.S. EPA (1990) and WHO (1991, 2003). However, the concentration of Zn is quite high, just below drinking limits, and could be a result of contamination from the landfill.

\section{Conclusion}

Top layers of stream sediments seem to interact with chemically modified run-off waters from the landfill. Trace elements analyses showed that the content of $\mathrm{As}, \mathrm{Cu}, \mathrm{Zn}$, and $\mathrm{Pb}$ is higher in the stream sediment than the uncontaminated samples. Since stream sediments interact with run-off waters from the landfill this is an indication of contamination from the landfill. SEM-EDS analyses revealed the presence of $\mathrm{Cl}^{-}, \mathrm{SO}_{4}{ }^{2-}$ as well as $\mathrm{Cu}$ in clay minerals, indicating that clay mineral surfaces adsorb pollutants.

The concentrations of $\mathrm{SO}_{4}{ }^{2-}$ and $\mathrm{NO}_{3}{ }^{-}$in groundwater are attributed to agricultural chemicals or fertilizers in the soil. $\mathrm{Cl}^{-}$concentration is quite high in the groundwater sample and is also attributed to human activities. The $\mathrm{Zn}$ content is also high, although just below drinking limits, and is a result of human induced contamination from the landfill.

Special concern should be given during the environmental monitoring of the landfill to ensure that no contaminants that may affect public health and the surrounding environment are released from the landfill.

\section{References}

Brooker, MP., and Johnson, PC., 1984. Behaviour of phosphate, nitrate, chloride and hardness in 12 Welsh rivers, Water Research, 18(9), 1155-1164.

Cavallaro, N., 1982. Sorption and fixation of $\mathrm{Cu}$ and $\mathrm{Zn}$, and phosphate by soil clays as influenced by the oxide fraction. PhD thesis. Cornell Univ. (Diss. Absr. 82-10799).

California Environmental Protection Agency, 1997. available at: http://www.oehha.ca.gov/ water.html

Chalermyanont, T., Arrykul S., and Charoenthaisong N., 2009. Potential use of lateritic and marine clay soils as landfill liners to retain heavy metals, Waste Management, 29, 117-127.

Churchman, G.J., Gates, W.P., Theng, B.K.G., and Yuan, 2006. Clays and Clay Minerals for Pollution Control. In: Developments in Clay Science Vol.1., Handbook of Clay Science, Bergaya, F., Theng, B.K.G. and Lagaly, G. (Eds). 625-676pp.

Department of National Health and Welfare (Canada), 1978. Guidelines for Canadian drinking water quality. Supporting documentation. Ottawa,

Doula, M.K., and Ioannou, A., 2003. The effect of electrolyte anion on $\mathrm{Cu}$ adsorption-desorption b y clinoptilolite, Microporous Mesoporous Materials, 58, 115-130.

Doutsos, Th., Kontopoulos, N., and Ferentinos, G., 1985. Das westliche Ende des Korinth-Grabens. (The western end of the Corinth graben.), Neues Jahrbuch fur Geologie und Palaontologie - Abhandlungen, 1985, 11, 652-666.

Doutsos, Th., Kontopoulos, N., and Poulimenos, G., 1988. The Corinth -Patras rift as the initial stage of continental fragmentation behind an active island arc (Greece), Basin Research, 1, 177-190.

Environmental Protection Agency (US EPA):: 1990, Seminar Publication: Assessment, Management and Communication of Drinking Water Contamination. Washington, USA.

European Council Directive 80/778/EEC concerning Drinking Water Quality of 15/7/1980. http://ec.europa.eu/environment/enlarg/handbook/water.pdf 
European Council Directive 1999/31/EC of 26 April 1999 on the landfill of waste. http://eur-lex.europa.eu/LexUriServ/LexUriServ.do?uri=CELEX:31999L0031:EN:NOT

Fatta, D., Papadopoulos A., and Loizidou, M., 1999. A study on the landfill leachate and its impact on the groundwater quality of the greater area. Environmental Geochemistry and Health, 21, 175-190.

Gibbs, R.J., 1970. Mechanisms controlling world water chemistry, Science, 170, 1088-1090.

Gibbs, R.J., 1973. Mechanisms of trace metal transport in rivers, Science, 180, 71-73.

Gonçalves, M.A., Nogueira, J.M.F, Figueiras,J., Putnis, C.V., and Almeida, C., 2004. Base-metals and organic content in stream sediments in the vicinity of a landfill, Applied Geochemistry, 19, 137-151.

Harding, S.C., and Brown H.S., 1978 Distribution of selected trace elements in sediments of Pamlico River Estuary, North Carolina, Environmental Geology, 1(2), 181-191

Hermanns Stengele, R., and Plötze, M., 2000. Suitability of minerals for controlled landfill and containment, EMU Notes in mineralogy, 2(8), 291-331.

Kalbe,U., Müller, W.W., Berger, W., and Eckardt, J., 2002. Transport of organic contaminants within composite liner systems, Applied Clay Science, 21, 67-76.

KORONIS SA., ENVITEC A.E., (1996). 'Sanitary Landfill Of the Municipality Of Patras' Booklet for the progress of works in the Landfill of Patras.

Kjeldsen, P., Bjerg, P., Rugge, K., Pedersen, J. K., Skov, B., Foverskov, A.,Wurtz, S., Christensen, T. H., 1993. Assessing the variability in leachate migration from an old municipal landfill, in: R. Cossu, H. T. Christensen and R. Stegmann (eds) Proceedings Sardinia 93, Fourth International Landfill Symposium. Sardinia, Italy, 1519-1531pp.

Mantei, E.J., and Coonrod D.D., (1989), Heavy metal content in the stream sediments adjacent to a sanitary landfill, Environmental Geology and Water Science, 13(1), 51-58.

Mantei, E.J., and Foster M.V., 1991. Heavy Metals in Stream Sediments: Effects of Human Activities, Environmental Geology and Water Science, 18, 2, 95-104

McBride, M.B., 1985. Sorption of Copper(II) on Aluminum Hydroxide as affected by phosphate, Soil Science Society of America Journal, 49, 843-846.

McLean, J. E., and Bledsoe B.E., 1992. Behavior of Metals in Soils. In (eds.): Boulding J.R., EPA Environmental Assessment Sourcebook. 19-56 pp.

Morales, E.C., 1987. Chemical quality of deep well waters in Cavite, Philippines, Water quality bulletin, 12(1):43 45 .

Moore, D.M., and Reynolds, R.C.Jr., 1989. X-Ray Diffraction and the Identification and Analysis of Clay Minerals. Oxford University Press. New York, 198-269pp.

National Toxicology Program (NTP) 2002. http://ntp.niehs.nih.gov/

Phelan, D.J., 1987. Water levels, chloride concentrations, and pumpage in the coastal aquifers of Delaware and Maryland. US Geological Survey, 1987 (USGS Water Resources Investigations Report 87 4229; Dialog Abstract No. 602039).

Ramamoorthy, S., and Rust, B.R., 1978. Heavy metal exchange processes in sediment water systems, Environmental Geology, 2(3):165-172

Rule, J., 1986. Assessment of trace element geochemistry of Hampton Roads Harbor and Lower Chesapeake Bay area sediments, Environmental Geology, 8(4):209-219

Sinex, S.A., and Helz, G.R., 1981. Regional geochemistry of trace elements in Chesapeake Bay sediments, Environmental Geology, 3, 315323

Stief, K., 1986. Das Multibarrierenkonzept als Grundlage von Planung, Bau, Betrieb und Nachsorge von Deponien, Müll und Abfall, 18(1), 15-20. 
Technical Instructions Hazardous Wastes (TA Abfall), (1991). Zweite Algemeine Verwaltungsvorschrift zum Abfallgesetz, Teil 1: Technische Anleitung zur Lagerung, chemisch/physikalischen und biologischen Behandlung, Verbrennung und Ablagerung von besonders überwachungsbedürftigen Abfällen vom 12.03.1991. Gemeinsames Ministerialblatt, 8, 139.

Wang, P.G., Ji G.L., and Yu, T.R., 1987. Adsorption of chloride and nitrate by variable charge soils in relation to electric charge of the soil, Zeitschrift Fur Pflanzenernahrung Und Bodenkunde, 150: 17-23.

WHO Regional Office for Europe, 1978 (EURO Reports and Studies 2). Sodium, chlorides, and conductivity in drinking water: a report on a WHO working group. Copenhagen,

WHO, World Health Organization, 1991. Revision of the WHO Guidelines for Drinking Water Quality, Report of the Second Review Group Meeting on Inorganics, Brussels, Belgium, Geneva, $\mathrm{WHO} / \mathrm{PEP} / 91: 32,12 \mathrm{pp}$.

WHO, World Health Organization, 2003. Guidelines for drinking-water quality, 2nd ed. Vol. 2. Health criteria and other supporting information, WHO/SDE/WSH/03. 04/03, Geneva.

Undabeytia, T., Nir, S., Rytwo, G., Serban, C., Morillo, E., Maqueda, C., 2002. Modeling AdsorptionDesorption Processes of $\mathrm{Cu}$ on Edge and Palnar Sites of montmorillonite, Environmental Science \& Technology, 36, 2677-2683.

Yanful, E.K., Quigley, R.M., and Nesbitt, H.W., 1988. Heavy metal migration at a landfill site, Sarnia, Ontario, Canada-2: Metal partitioning and geotechnical implications, Applied Geochemistry, v. 3, p. 623-629.

Zelilidis, A., Koukouvelas, I., and Doutsos, Th., 1998. Neogene paleostress changes behind the forearc fold belt in the Patraikos Gulf area, Western Greece, Neues Jahrbuch fur Geologie und Palaontologie - Abhandlungen, 1998, 311-325. 